Primljen / Received: 2.2.2017. Ispravljen / Corrected: 21.2.2018. Prihvaćen / Accepted: 13.3.2018. Dostupno online / Available online: 10.4.2018.

\section{Stone and mortar in bridges from the Ottoman period in Bosnia and Herzegovina}

Authors:

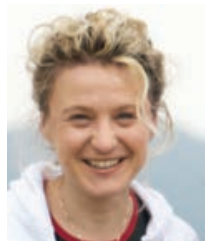

Assoc.prof. Naida Ademović, PhD. CE University of Sarajevo Faculty of Civil Engineering naidadem@yahoo.com

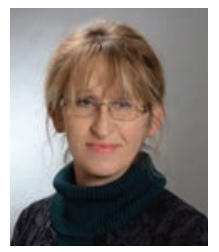

Assoc.prof. Azra Kurtović, PhD. CE University of Sarajevo Faculty of Civil Engineering azra_kurtovic@gf.unsa.ba

\section{Naida Ademović, Azra Kurtović}

\section{Stone and mortar in bridges from the Ottoman period in Bosnia and Herzegovina}

Main parameters for the construction of stone bridges, and major factors for selection of new (replacement) stone and mortar, are presented in the paper. Laboratory test results are given for the stone and mortar normally used in the rehabilitation and reconstruction of cultural and historical heritage structures from the Ottoman period in Bosnia and Herzegovina. A special attention is paid to physical and mechanical characteristics of tufa, travertine and limestone, as basic materials used in the construction of such structures.

\section{Key words:}

cultural and historical heritage, mortars, stone, hydraulic additives, restoration, laboratory testing

Prethodno priopćenje

Naida Ademović, Azra Kurtović

\section{Kamen i mort kod mostova iz razdoblja Osmanskog Carstva u Bosni i Hercegovini}

U radu su prikazani glavni parametri gradnje kamenih mostova te bitni čimbenic pri odabiru novog (zamjenskog) kamena i morta za gradnju. Opisani su rezultati laboratorijskog ispitivanja kamena i morta koji se uobičajeno koriste kod sanacije rekonstrukcije građevina kulturno-povijesne baštine u Bosni i Hercegovini iz perioda osmanske vladavine. Posebna pažnja je posvećena ispitivanju fizikalnih i mehaničkih karakteristika sedre, travertina i vapnenaca kao osnovnih kamenih materijala koji su korišteni prilikom izgradnje takvih konstrukcija.

Ključne riječi:

kulturno-povijesna baština, mortovi, kamen, hidraulični dodaci, restauracija, laboratorijska ispitivanja

Vorherige Mitteilung

Naida Ademović, Azra Kurtović

\section{Stein und Mörtel bei Brücken aus der Zeit des Osmanischen Reichs in Bosnien und Herzegowina}

In der Abhandlung sind die Hauptparameter des Baus von Steinbrücken sowie wichtige Faktoren bei der Wahl eines neuen (Ersatz-) Steins und Mörtels für den Bau dargelegt. Beschrieben werden Ergebnisse der Laboruntersuchungen des Steins und Mörtels, die üblicherweise bei der Sanierung und Rekonstruktion von Gebäuden des kulturhistorischen Erbes aus der Zeit des Osmanischen Reichs in Bosnien und Herzegowina verwendet werden. Besondere Aufmerksamkeit wird der Untersuchung der physikalischen und mechanischen Eigenschaften von Tuffstein, Travertin und Kalkstein als grundlegende Steinmaterialien gewidmet, die beim Bau solcher Konstruktionen verwendet wurden.

Schlüsselwörter:

kulturhistorisches Erbe, Mörtel, Stein, hydraulische Zusätze, Restaurierung, Laboruntersuchungen 


\section{Introduction}

Besides representing basic elements of national infrastructure, bridges are often considered to be significant indicators of the power and prosperity of a particular period. They are a permanent symbol of the Ottoman Empire rule in Bosnia and Herzegovina. Although a large number of wooden and stone bridges were built in that period, only those made of the most lasting material, stone, still bear witness of these far-gone times. An axonometric view of basic elements of a single arch stone bridge is shown in Figure 1.

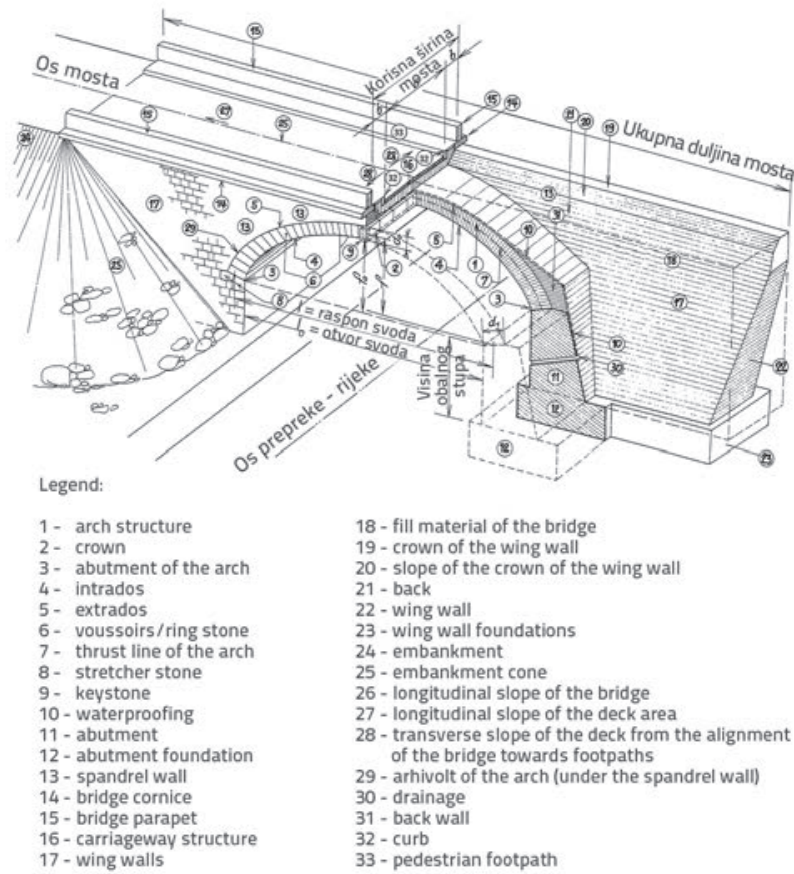

Figure 1. Axonometric view of stone bridge [1]

When processing stone for use in a masonry structure, the first working operation is usually the stone splitting so that a suitable form for grinding and further processing can be obtained. Completely carved or semi-finished stone is processed in free form from natural banks or from already cut out regular pieces of stone. Pieces of stone and smaller monoliths can be carved as a fully-scaled stone (fully carved stone with a prominent middle part of the forehead) and as semi-finished stone with a flat front surface. The shape of the stone element that is being processed represents a carving characteristic as well. The form is usually parallelopipedic or prismatic, although the form can also be quite complex. The level, quality, and content of processing depends on the tools used in the cutting process. A good master carves stone as skilfully as a sculptor [2]. Special attention has to be paid to the appearance and stability of the structure being built by carved stone. When special aesthetic effects and decorative elements such as cornices, fences, plastic ornaments, etc. are required, and when large pressures are expected during construction, special care is required during transport and installation of stone masonry so that the stone built into the structure remains undamaged. Figure 2 shows the face of a wall made of semi-finished and carved stone.

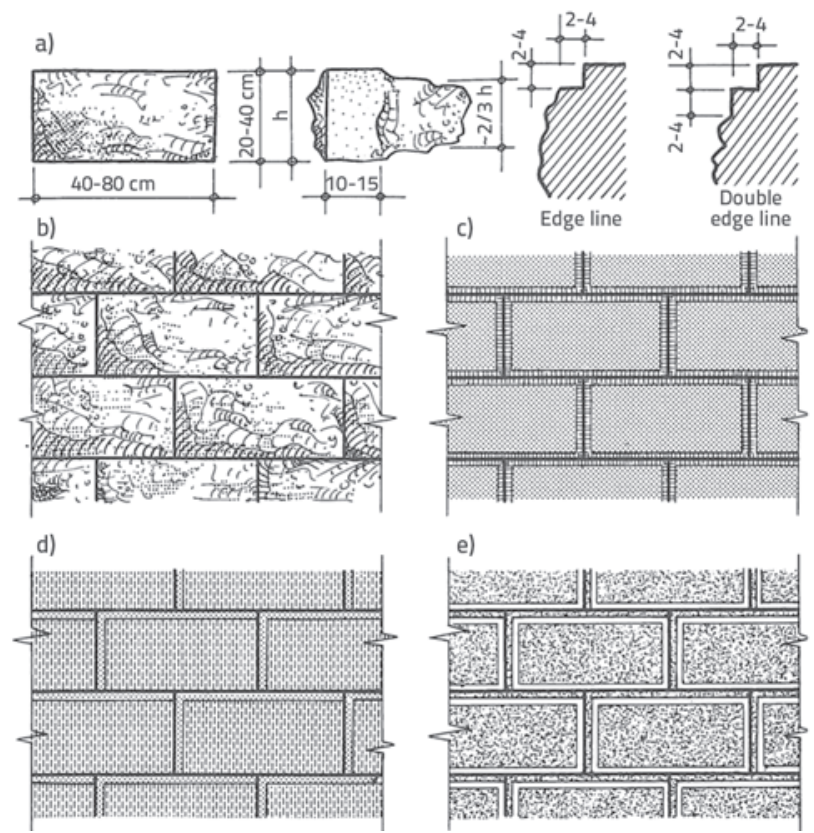

Figure 2. Face of the wall made of semi-finished stone: a) basic shape and detail of edge stone elements; b) face of the wall with rubbed finishes and without joints; c) with joints and flat surface of the elements; d) joints made only up and left; e) partly double joints [3]

The arches and piers of the bridge can be constructed in such a way that visible surfaces of the arch are realised using carved or semifinished stone, and that only the body - the infill of the arch or the pillar - is realised using broken or roughly trimmed stone (usually a flat broken stone is considered appropriate). In this case, spandrel walls and a part of the arch made of broken stone or paved stone have to be constructed at the same time (Figure 3).
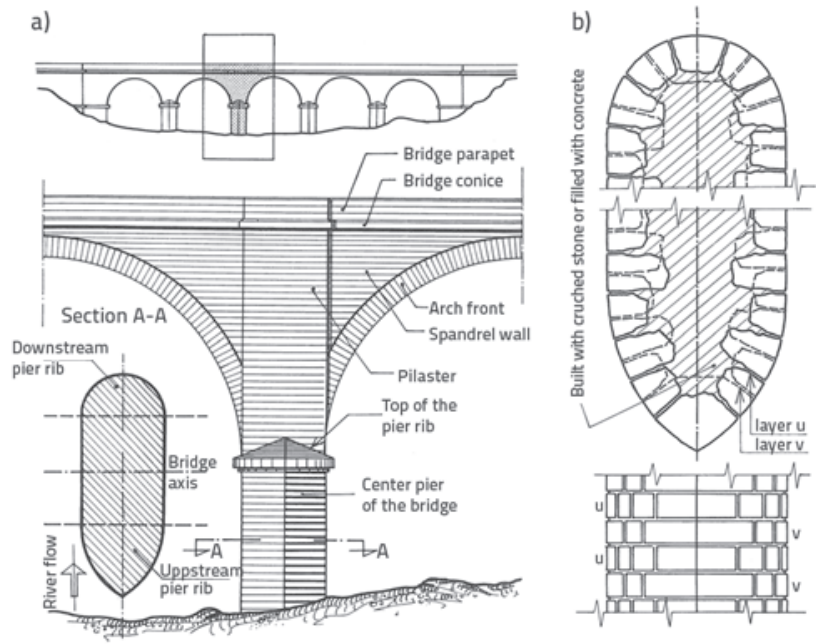

Figure 3. a) Central pier of a bridge with several arches; b) layers of semi-finished stone - horizontal cross section of the bridge pier [1]

To ensure that the deformation of the arch does not affect the stability and deformation of spandrel walls, the spandrel walls are built after laying the masonry and curing the mortar in the joints 
of the arch. This is done after removal of the scaffolding and after execution and settlement of the arch. As the construction of spandrel walls imposes a directload onto the arch, these walls should preferably be made of lighter stone. The appearance of spandrel walls has a considerable influence on general appearance of stone bridges. Different varieties of limestone were used in order to place emphasis on spandrel walls of some bridges, such as the Šeher-Ćehajina Ćuprija in Sarajevo. In most cases, a spandrel wall represents a wall that is monolithically connected with the coherent filling of the bridge. For larger spans, masonry construction can be performed in lamellae or rings due to symmetric and uniform loading of the scaffolding (Figure 4). The order of construction of lamellae should enable a uniform and clearly defined transfer of load to the scaffold. In the arches made in rings, unlike the lamellae, the construction is not carried out across the entire thickness, but rather in rings (each ring is constructed in lamellae). After completion of one ring, which can take over the load of the scaffolding and the second ring, the second ring is constructed in an identical manner, and so on until the entire arch is completed.

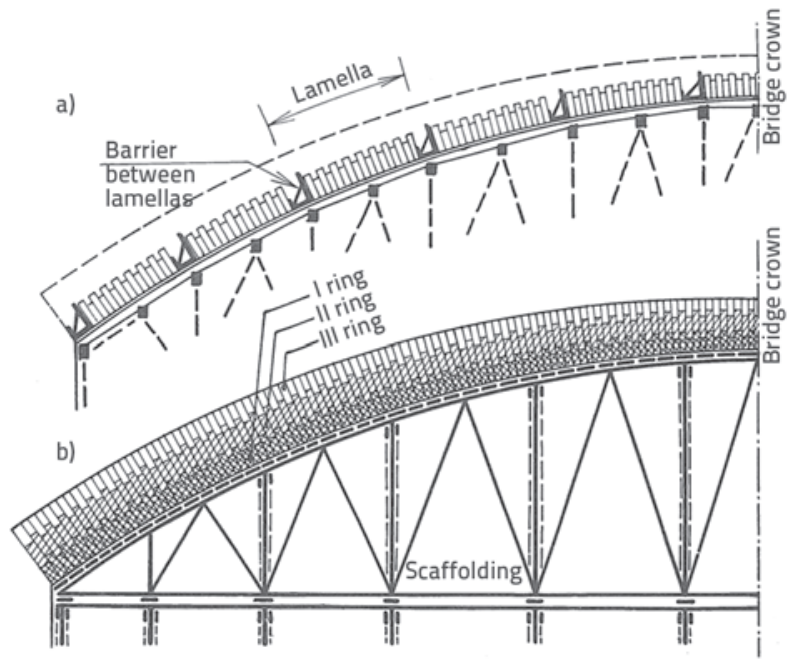

Figure 4. Arch construction: a) arch construction in lamellas; b) arch construction rings [3]

With regard to its carrying capacity, the basic mechanical characteristic of stone is its compressive strength, which has significant deviations even for the same petrographic rock type. The tensile strength of stone is also important: it amounts to approximately 20x less than the compressive strength, while the flexural strength is about 10x less than the compressive strength. It is known that the state of stress of masonry structures is very complex. That is why a lot of attention is nowadays paid to adequate modelling and calculation of such structures. The bearing capacity depends on individual characteristics of these materials (stone and mortar), and on adequacy of the stonemortar connection. However, it must be emphasized that the quality of mortar is of crucial importance, as it represents the weakest link in such structures. The appearance and stability of a stone-built element is greatly affected by the processing of joints between stone blocks (Figure 5). The better the dressing/ finishing of masonry stone the thinner the joints can be, and vice versa. The size of sand grains for mortar is selected and determined according to the thickness of the joint. The closing of joints is performed using a quality mortar at a length equal to double thickness of the joint (usually $4-5 \mathrm{~cm}$ ) [3].

Lime mortars were used during the Ottoman period. Due to some additives in form of reddish, crushed, and gritted bricks, combined with various organic substances, such mortars exhibited a relatively high compressive strength attaining up to $30 \mathrm{~N} / \mathrm{mm}^{2}$. The adhesion of mortar to stone surface is of great importance for good connection and adequate load transfer. The adhesion is higher if the surface is rougher and if the stone is more porous.

Determination of characteristics of historical lime mortars gained in significance in the second half of the $20^{\text {th }}$ century. Detailed studies on historical lime mortar were published by Hansen et al. in GCI Project Bibliographies Series [4]. This work represents a notable source of information for preservationists and scientists involved in this field.

One of the aspects that has not as yet been fully explored is whether the hydraulicity of historical lime mortars originates from a mixture of pozzolan with lime, or it is due to the use of hydraulic lime. Investigations carried out on the Ottoman spa structures [5] revealed that calcium silicate can be produced at relatively low temperatures of calcination $\left(850^{\circ} \mathrm{C}\right)$. Based on this discovery, it can be concluded that hydraulic lime was used at that time (15 $15^{\text {th }}$ century) and that compressive strengths of mortar were even then quite significant [5].

\section{Geotectonic features of Bosnia and Herzegovina}

Bosnia and Herzegovina is divided into three Dinaric zones: the outer Dinaric belt (No.1), the central Dinaric belt (No.2) and the inner Dinaric belt (No. 3) as shown in Figure 6. Figure 7 shows the geological map of Bosnia and Herzegovina.

The most widely spread calcite aggregates are cretaceous rocks or limestone. In Bosnia and Herzegovina, the limestones are made of calcium, and they spread out for thousands of kilometres. These limestones belong to several geological ages: Palaeozoic, Mesozoic, and Cainozoic. Calcite is present to some degree in bauxite originating from Vlasenica and Herzegovina. In the Palaeozoic regions of Bosnia and Herzegovina, calcite is 
important and, in some areas, it is even the only component of crystalline limestone, marble, and limestone phyllite.

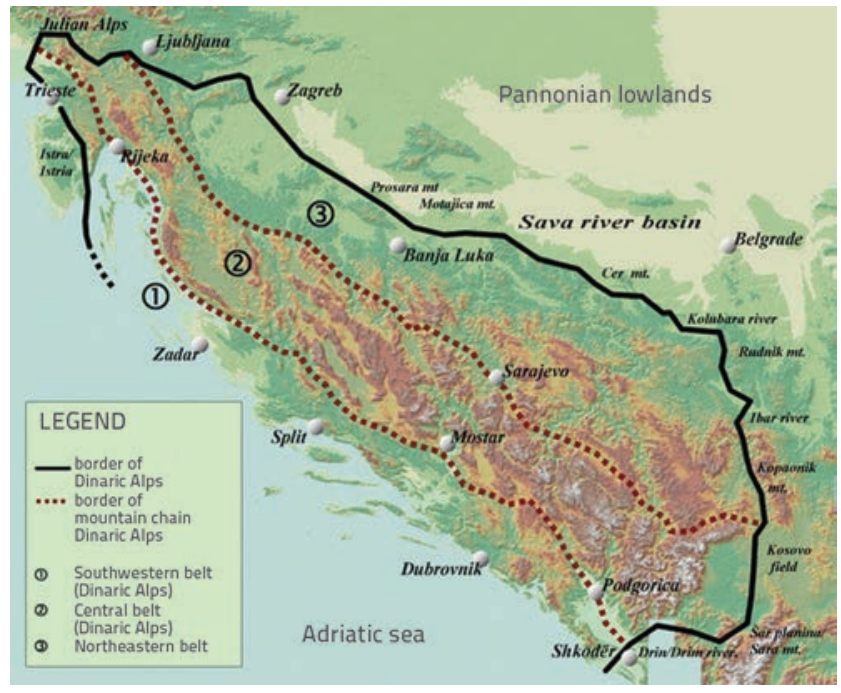

Figure 6. Geotectonic Division of Dinarides in B\&H [6]

Palaeozoic deposits are predominantly clastic, locally with carbonate structures, which have been transformed in some places. Palaeozoic deposits are found mostly in the Una-Sana area, in the central Bosnian slate mountains, in eastern and south-eastern Bosnia, and in Posara and Motajica. The Central Bosnian Palaeozoic complex extends from Ivan Sedlo in the southeast to Jajce in the northwest, and from Sarajevo-Zenica Basin in the northeast to the Upper Vrbas Uskoplje Basin in the southwest. Palaeozoic in southeastern Bosnia is the so-called Praća Palaeozoic, and it extends to the east and northeast of Jahorina and the Drina River.

Limestone rocks from Devonian and Carboniferous are mainly found in the Praća Palaeozoic. Northeast of the Praća Palaeozoic is the Drina Palaeozoic, which stretches from the region of Srebrenica to Zvornik. Palaeozoic deposits were developed around Ključ and Sanski Most. This area is called the Una-Sana Palaeozoic. Here, the Carboniferous is made of various clastites, having magma rocks as well, and some dolomite and limestone (Figure 7). For calcite found in Bosnia and Herzegovina, it can be stated that it is a unique mineral, created in all three geological environments: sedimentary, magmatic and metamorphic. The largest area of Bosnia and Herzegovina is made of limestone of the Mesozoic and Cainozoic age; especially in the so-called outer Dinaric belt (Figure 6). The Mesozoic limestone belongs to the Triassic, the Jurassic and the Cretaceous, and extends to several thousand meters in thickness. Mesozoic deposits are widespread in the inner, central and outer Dinaric belts. Mesozoic deposits in the outer Dinaric belt are represented by traditional carbonate deposits, while

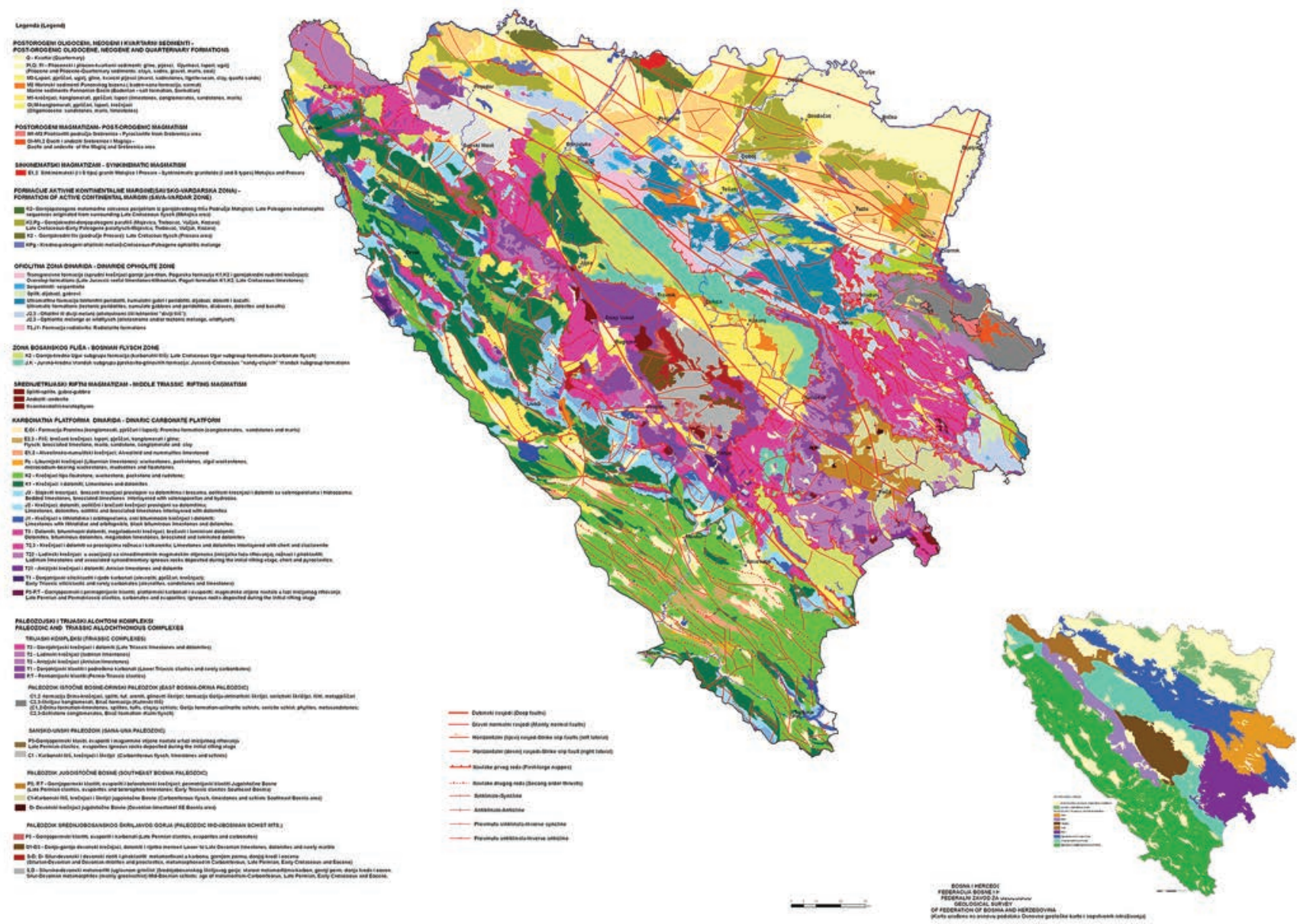

Figure 7. Geological map of Bosnia and Herzegovina [7] 
the central and inner Dinaric belts are characterized by volcanicsedimentary and flysch deposits (Figure 7). Tertiary limestones are predominantly of Paleogene age, while limestones of Neogene era are only locally encountered. Jurassic deposits occupy the largest part in the outer Dinaric belt, where they are mostly developed in the limestone-dolomite facies [8].

\section{Stone used in construction - tufa, travertine and limestone}

Stone and mortar were used as basic building materials in masonry structures of the Ottoman period. The stone used for masonry and facing of cultural and historical heritage structures belongs to the category of architectural construction stone. The elements of the Ottoman period bridges were made of finely processed, carved/ cut stone, while the crushed stone was used for filling larger sections. Crushed stone is a material of irregular shape obtained from rock mass. Due to anisotropy of the rock mass, sedimentary rocks (travertine, tufa, sandstone, and limestone) do not adhere to any rule when it comes to the shape and representation of a certain bulk of crushed stone. Two basic types of stone used were tufa and limestone, which belong to sedimentary rocks. From this perspective, looking at locations of these bridges, it is very likely that the location of quarries of these materials determined the micro-location of bridges from the Ottoman period (why the Drina was bridged specifically in Višegrad, or why the Neretva in Mostar and Konjic in the $16^{\text {th }}$ and $17^{\text {th }}$ centuries?). However, the question arises as to why tufa, tenelija stone, sandstone, and limestone? We will try to provide the answer in the following sections.

\subsection{Tufa}

In that period, the main reason for choosing tufa as a building material was its ease of processing and a relatively low apparent density. It is known that as long as it contains natural moisture, it can easily be sawn with a common saw. The loss of moisture results in increased hardness, which is a result of the extraction of calcium carbonate from calcium bicarbonate, contained in moisture. On many ancient buildings, tufa has endured and maintained its integrity for hundreds of years. However, there are cases of its disintegration under atmospheric influence [9]. Tufa is a rock, i.e. a calcium carbonate by chemical composition, produced by extraction from cold water rich in calcium bicarbonate and abounding in aquatic plants and grass. It is a result of complex series of interactions and processes that are simply called precipitation (the formation of the solid phase was either crystalline or amorphous from solution) $[10,11]$. Irregular and tubular cavities of large diameter, formed as a product of vegetation loss, give this rock a specific hollowly - spongy look, its low density, and extremely high porosity. Tufa is usually of light brown, slightly yellowish colour, and has a solid structure. The texture of the rock is massive-hollowly, while the structure is fine crystalline and partly oolitic. Interestingly, there is a noted contradiction about the amount of tufa in the quarries in Bosnia and Herzegovina. Thus, it is reported in [8] that there are relatively large quantities of calcite rocks in the form of tufa or travertine along the riverbeds or at their waterfalls (the Pliva, Una, Trebižat, Drina, Neretva and other rivers). On the other hand, it is stated in [12] that these are small quantities, even in terms of rarity in small deposits in individual rivers, or as significant components at open-cut limestone mines (Prusac-Donji Vakuf, Sedra near Cazin). Tufa is a stone material that has been used since ancient times for construction of masonry elements of bridges.

\subsection{Travertine}

In Bosnia and Herzegovina, there are significant quantities of travertine in the area of Divčane near Jajce. This material bears a commercial name Plivit Jajce, and was also used in the construction of structures in the Ottoman period. Unlike the famous tufa from the lakes at Jajce locality, the Plivit - Jajce travertine is generally characterized by moderate hollowness and a striped-layered structure. Travertines are moderate solid rocks that can readily be processed. They are formed by inorganic secretion of calcite from the hot water of thermal springs.

The name travertine is derived from the Lapis tiburtinus or the stone from Tibur (the ancient name for today's Tivoli) as it was called by ancient Romans [9]. Due to its striped-layered structure, travertine exhibits a variety of forms, depending on the direction of cutting. Thus, strips are formed by cutting the stone perpendicular to the rift, while the strip form disappears and an uneven hollowness and a specific annular shape pattern is obtained if the material is cut parallel to the layers. The strength and hardness increases with the loss of natural moisture.

\subsection{Limestone}

Limestone was used for riverbank walls, as bridge cobble stone, and for the lower parts of the structure to the height that can be attained by water at higher water levels. Limestones are a very significant natural building material. They are relatively easy to handle (carved limestone, cut pieces, slabs) and are hence built into various building structures, monuments, etc. [8].

\section{Selection of stone for restoration of old buildings}

There are very few old buildings for which there are records about the quarry that was used as a source of stone. Such data are most often available for the Ottoman period bridges for which very large quantities of stone were needed.

Special significance was given to the selection of petrographic stone types and the possibility of selecting a local quarry (tenelija from Mukoše near Mostar and limestone probably from Opine Mostar the Old Bridge in Mostar; tufa from Višegradska Banja and limestone probably from Klašnik - the Old Bridge in Višegrad, etc.).

Very often, after obtaining a record of the stone quarry, it was noted that the quarry is abandoned and neglected, covered with vegetation, with no open exploitation field. However, since in most cases there are no written records on the origin and location of the initially built-in stone, a special procedure must be carried out to identify and select a new (replacement) stone that should correspond, 
as much as possible, to the original stone initially built into the structure. The specificity of the problem of restoration, rehabilitation, reconstruction and conservation of masonry stone elements does not only imply identification of petrographic type and determination of stone properties, but also includes finding the quarry from which the stone was extracted. Numerous times during the restoration and reconstruction of cultural heritage structures in Bosnia and Herzegovina, which is the area of the rich past, insurmountable obstacles were encountered in finding specific types of stone. Some of the notable examples illustrating this point include reconstruction of the City Hall in Sarajevo, construction of the Ferhadija Mosque in Banja Luka, conservation and restoration of the facade of the Central Bank in Sarajevo, reconstruction of the Latinska ćuprija (Latin Bridge) in Sarajevo, etc. The reason is usually the fact that long-lived stonebuilt sacral structures (cathedrals, monastic churches, mosques) and secular buildings (towers, fortresses, castles and residential buildings) were built over a long period of time using very specific types of materials. It is not surprising that stone elements for such important structures were donated by good people from far away, and transported for months to the destination by horse carriage, as this was then the only means of transport. Unfortunately, records of donors were not preserved for most of the buildings.

The review of available literature shows that, in most cases, bridges built in the Ottoman period in Bosnia and Herzegovina were made of very porous lightweight stone (tufa, travertine, sandstone) and compact limestone of low porosity originating from nearby localities. In identifying the initially built-in stone and choosing a new (replacement) stone, with or without written records, it is necessary to submit the stone to appropriate field and laboratory testing. These on-site and laboratory tests enable comparison of the existing stone with the replacement stone. The following tests and analyses are normally conducted: mineralogical-petrographic analysis (macroscopic and microscopic analyses defining mineral composition, structure, texture, cracks, main and harmful components, insoluble residues in carbonate rocks) chemical analysis (quantitative and qualitative analysis), determination of apparent and actual density, total and open porosity, water absorption, compressive and flexural strength under concentrated load, resistance to atmospheric effects (also an indicator of resistance to frost action), and resistance to wear.

In addition to these investigations, special tests are sometimes also conducted and specific parameters are determined using non-destructive and slightly destructive methods. Destructive methods cannot be used for cultural-historical structures, as irreversible damage would thus be made to such cultural and historical monuments. It is believed that all data needed for goodquality rehabilitation of structures can be obtained with adequate non-destructive and slightly destructive methods. For example, it has been thought for a long time that the Mehmed-Paša Sokolović Bridge in Višegrad was initially built using good-quality Višegrad tufa. According to the available archives on the construction of this bridge, it was established that the stone used for the construction of the bridge was taken from the vicinity of the bridge, i.e. from Višegradska Banja "Vilina Vlas", which has not been exploited for many years. The stone used for reconstruction of the bridge in Konjic and bridge in Sarajevo (Šeher-Ćehajina cuuprija) originates from the tufa quarry in Prusac, Donji Vakuf, which is currently the largest and best-preserved tufa site in Bosnia and Herzegovina.

Proper and adequate sampling and formation of a representative sample is a significant issue in the process of choosing substitute stone for the restoration of cultural and historical structures, and generally in the examination of natural stone properties.

Selecting a representative sample of natural stone is very demanding and should be performed by an expert having confirmed technical competence in the field of sampling and testing of natural stone properties.

It should be pointed out that visual inspection and selection of representative samples is very difficult for the stone exhibiting large and extreme porosity with open cavities, such are limestone and tufa, due to visually unequal representation of cavities, their filling, and connections.

\subsection{Physical and mechanical characteristics of tufa and travertine}

The blocks or monoliths exhibiting intensive mechanical damage, e.g. visible cracks, macro cracks and cavities, were not used during sampling in open stone quarries. Selected samples were examined to determine layering of stone material, i.e. the bearing or rift surface was clearly indicated, and sample orientation according to the position in the rock mass of the quarry was properly labelled. This was done in order to accurately define the direction of the layers. When sampling the stone, special attention was paid to the representability of individual samples in terms of homogeneity, structure and texture. Stone samples, taken from different locations in form of roughly processed rectangular and square parallelepipeds with a length of about $40 \mathrm{~cm}$, were tested to determine their flexural strength under concentrated load. During formation of a representative sample for the examination, a visual inspection, professional experience and detailed examination of the quarry was of crucial importance. Considering the specificities of the sedimentary, hollow and strip-layered material, it was necessary to form a large sample in the quarry and try to sample all macroscopically different textures of natural stone (at least 80 $\%$ of the rock mass). After this, a laboratory sample was formed by professional selection, and appropriate tests were conducted.

Table 1. Testing methods

\begin{tabular}{|c|c|c|c|}
\hline No. & Type of testing & Standard & $\begin{array}{c}\text { Sample } \\
\text { dimensions } \\
{[\mathrm{mm}]}\end{array}$ \\
\hline 1 & Apparent density & $\begin{array}{c}\text { BAS EN 1936:2009 } \\
\text { (EN 1936:2006, IDT) }\end{array}$ & $50 \times 50 \times 50$ \\
\hline 2 & Open porosity & $\begin{array}{c}\text { BAS EN 1936:2009 } \\
\text { (EN 1936:2006, IDT) }\end{array}$ & $50 \times 50 \times 50$ \\
\hline 3 & $\begin{array}{c}\text { Compressive } \\
\text { strength }\end{array}$ & $\begin{array}{c}\text { BAS EN 1926:2009 } \\
\text { (EN 1926:2006, IDT) }\end{array}$ & $50 \times 50 \times 50$ \\
\hline 4 & $\begin{array}{c}\text { Flexural } \\
\text { strength under } \\
\text { concentrated } \\
\text { load }\end{array}$ & $\begin{array}{c}\text { BAS EN 12372:2009 } \\
\text { (EN 12372:2006, IDT) }\end{array}$ & $50 \times 50 \times 300$ \\
\hline
\end{tabular}



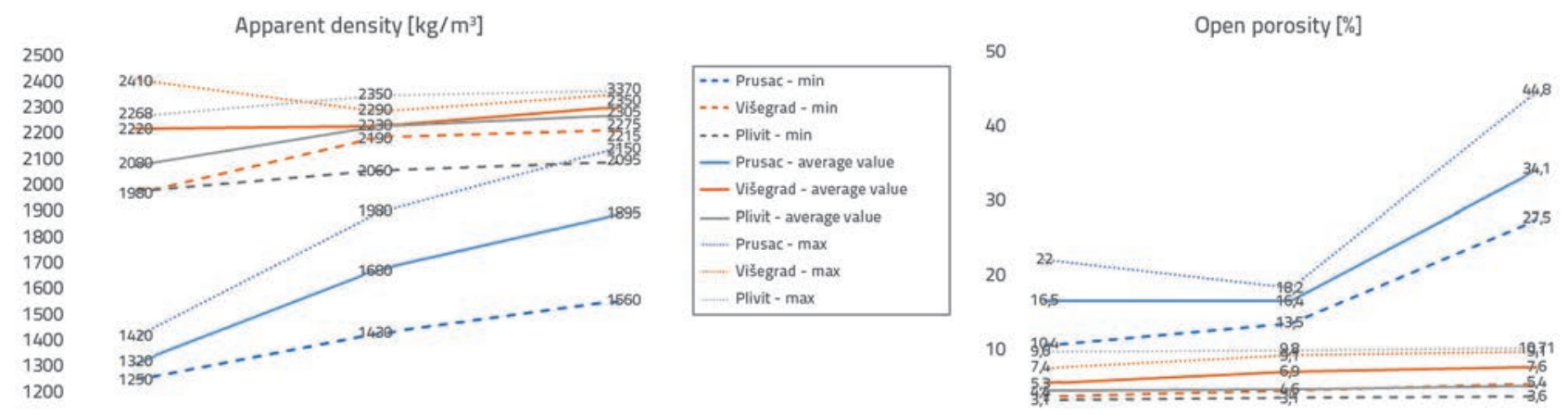

Figure 8. Physical characteristics of tufa and travertine (Plivit)
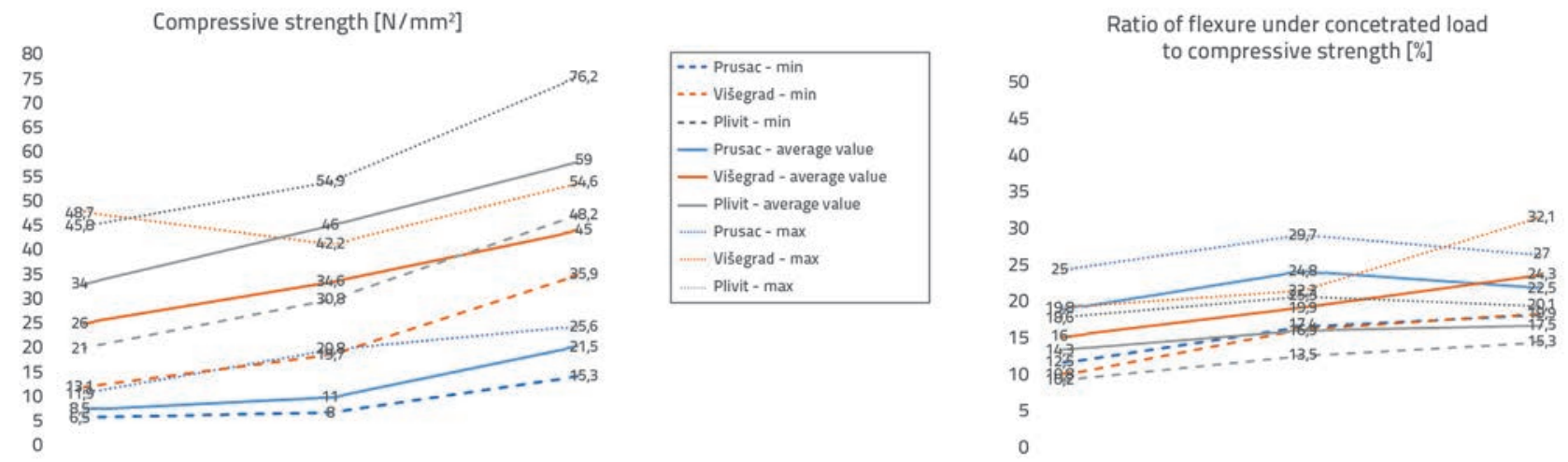

Figure 9. Mechanical characteristics of tufa and travertine (Plivit)

Laboratory tests were carried out for five years at the Institute for Materials and Structures of the Faculty of Civil Engineering in Sarajevo using material from the available quarries, i.e. the stone destined for the reconstruction of structures from the Ottoman period, as shown in Table 1. Test results are presented in Figures 8 and 9.

Figure 8 gives the basic physical characteristics, and Figure 9 the basic mechanical characteristics of the tufa and travertine (Plivit) that were used as a building material during rehabilitation of bridges from the Ottoman period in Bosnia and Herzegovina.

It can be seen in Figure 8 that the stone from Prusac quarry has a significantly smaller apparent density and more pronounced porosity, the average value being $34.1 \%$. As to other two stones the porosity is about $8 \%$ (quarries in Višegrad and Jajce). Significant compressive strengths can be noted in the case of travertine from Jajce (Figure 9), with an average value of $59 \mathrm{~N} / \mathrm{mm}^{2}$. The compressive strengths registered at the Višegrad and Prusac quarries were by $23.7 \%$ and $63.6 \%$ lower, respectively.

Depending on its mineral composition and structure, a petrographic stone type has a rather wide range of compressive strength values. Several strength categories can be differentiated. Both tufa and travertine may have very low strength (below $10 \mathrm{~N} / \mathrm{mm}^{2}$ and often below $5 \mathrm{~N} / \mathrm{mm}^{2}$ ) and low strength (10-50 N/mm²), while the compressive strength of limestone can be very high (over $250 \mathrm{~N} /$ $\mathrm{mm}^{2}$ ) but also quite low. Therefore, the petrographic determination of stone is not an indication of its strength. It must always be determined by testing [9].

It should be noted that the laboratory test results confirm that the ratio of flexural strength under concentrated load to compressive strength ranges from $14.3 \%$ to $24.3 \%$ for tufa and travertine, and that it is higher compared to other petrographic types. In most cases, the flexural strength under concentrated load of natural stone ranges from 7 to $20 \%$ of the compressive strength of the same stone.

\subsection{Physical and mechanical characteristics of limestone}

Limestone sampling was carried out using the abovementioned sampling principles, but taking into account the fact that, at the quarry locations, the blocks and monoliths that were avoided were the ones that were close to the explosion in the quarry, or close to vibration impact due to mechanical shock. Table 2 shows methods used for testing physical and mechanical properties of limestone.

Table 2. Testing methods

\begin{tabular}{|c|c|c|c|}
\hline No. & Type of testing & Standard & $\begin{array}{c}\text { Sample } \\
\text { dimensions } \\
{[\mathrm{mm}]}\end{array}$ \\
\hline 1 & Apparent density & $\begin{array}{c}\text { BAS EN 1936:2009 } \\
\text { (EN 1936:2006, IDT) }\end{array}$ & $50 \times 50 \times 50$ \\
\hline 2 & Open porosity & $\begin{array}{c}\text { BAS EN 1936:2009 } \\
\text { (EN 1936:2006, IDT) }\end{array}$ & $50 \times 50 \times 50$ \\
\hline 3 & $\begin{array}{c}\text { Compressive } \\
\text { strength }\end{array}$ & $\begin{array}{c}\text { BAS EN 1926:2009 } \\
\text { (EN 1926:2006, IDT) }\end{array}$ & $50 \times 50 \times 50$ \\
\hline 5 & $\begin{array}{c}\text { Flexural strength } \\
\text { under concentrated } \\
\text { load }\end{array}$ & $\begin{array}{c}\text { BAS EN 12372:2009 } \\
\text { (EN 12372:2006, IDT) }\end{array}$ & $50 \times 50 \times 300$ \\
\hline 5 & $\begin{array}{c}\text { Abrasion resistance, } \\
\text { method B (Böhme } \\
\text { machine) }\end{array}$ & $\begin{array}{c}\text { BAS EN 14157:2009 } \\
\text { (EN 14157:2004, IDT) }\end{array}$ & $71 \times 71 \times 71$ \\
\hline
\end{tabular}



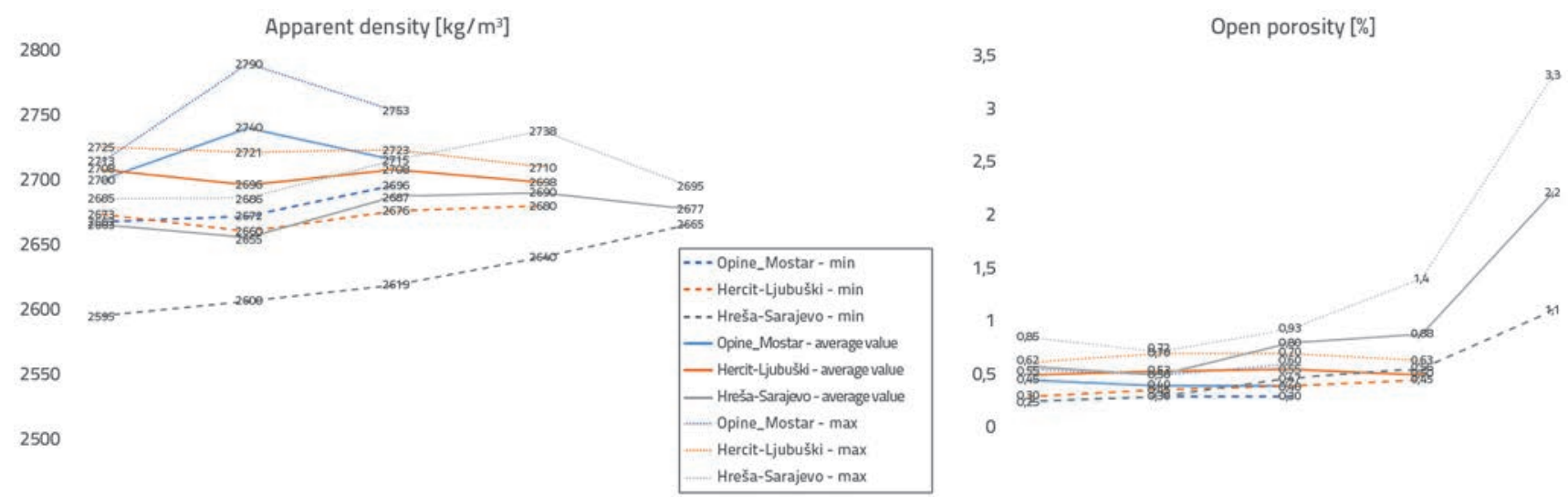

Figure 10. Physical characteristics of limestone

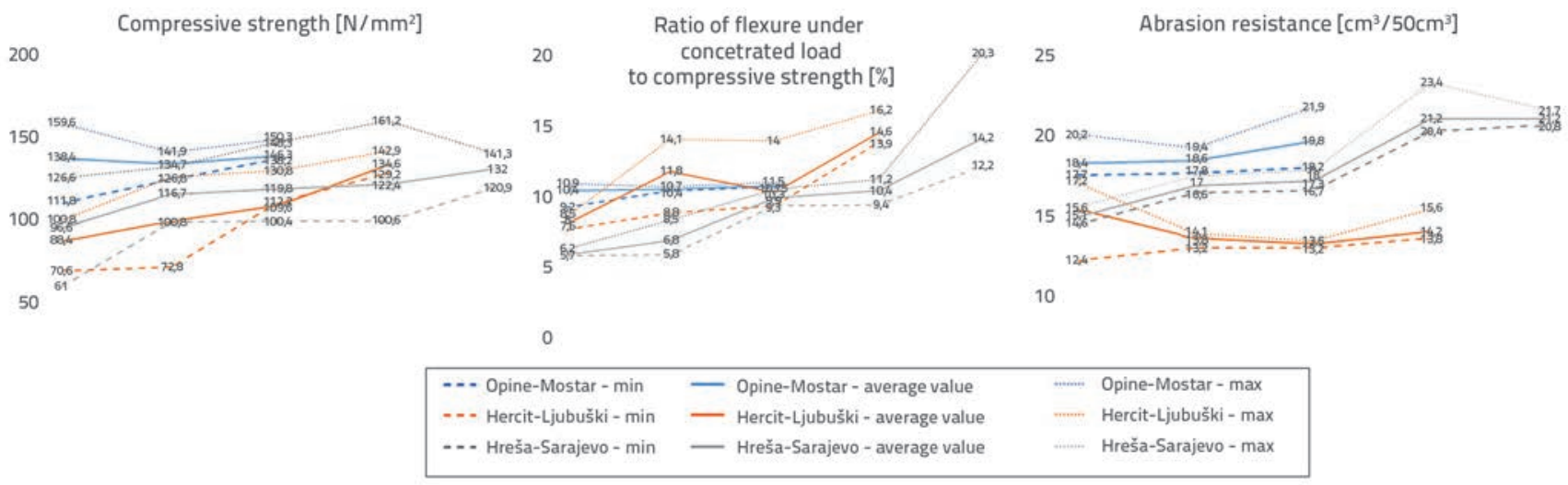

Figure 11. Mechanical characteristics of limestone

Basic physical and mechanical characteristics of limestone used in the repair of bridges are shown in Figure 10 and Figure 11 , respectively. It is evident from Figure 10 that the specific weight of limestone is rather uniform and that the average value ranges from $2655 \mathrm{~kg} / \mathrm{m}^{3}$ to $2740 \mathrm{~kg} / \mathrm{m}^{3}$. Open porosity is also rather uniform and ranges from $0.4 \%$ to $0.8 \%$, except for the results that indicated low frost resistance of stone (average value: $2.2 \%$ ).

Expectedly, the compressive strength of limestone, as related to tufa and travertine, is significantly higher and reaches an average value of $140.2 \mathrm{~N} / \mathrm{mm}^{2}$. It can be noted that the ratio of flexural strength under concentrated load to compressive strength is lower for limestone when compared to tufa and travertine (Figure 9 and Figure 11).

The value of abrasion resistance points to an adequate resistance of stone to abrasion by scraping. According to test results, all types of stone can be classified as hard stone (10-20 $\left.\mathrm{cm}^{3} / 50 \mathrm{~cm}^{2}\right)$ and moderately hard $\left(20-30 \mathrm{~cm}^{3} / 50 \mathrm{~cm}^{2}\right)$ stone.

\section{Mortar selection for restoration of old buildings}

Mortar is the second component that is considered highly important, and perhaps the most important, in the restoration of cultural and historical structures. An adequate choice of binder-mortar is a key factor for successful restoration of existing structures. Mortar is formed by mixing the binder (such as lime or cement) with water and aggregate/sand. International bodies, such as ICOMOS or ICCRORM, provide clear recommendations stating that it is necessary to apply materials of similar characteristics and composition as original materials during restoration works [8, 9]. As already mentioned, Hansen encompassed a bibliography based on the restoration and conservation of mortars. Compatibility must be ensured in several areas:

- chemical compatibility between replacement mortar and the existing material (masonry elements and existing mortar);

- physical compatibility, special attention should be paid to solubility processes and water transport;

- compatibility in structural and mechanical contexts, the strength of the mortar to be applied during restoration should be similar to that of the existing mortar.

In addition, according to [13], mortars used for restoration must satisfy the following criteria:

- mortar strength must not exceed the stone or brick strength

- water absorption and permeability of water vapour of the mortar must be of the same order of magnitude or greater 
compared to other masonry elements. In this way, water (and salt) accumulates in the mortar and so the latter can act as a "sacrificial element"

- mortar must exhibit minimum shrinkage in order to prevent cracking

- mortar should be well bonded with brick or stone. This is reflected in high plasticity and workability of mortar.

Since the invention of Portland cement, in the mid-nineteenth century, the use of hydraulic lime in mortar joints was reduced, and this material was largely replaced by cement-based mortars, even in restorations, which proved not only inadequate but also harmful [14] due to non-compliance with the above compatibility conditions [13,15]. As cement-based mortars are rigid materials with high compressive strength, they can cause high local stresses that can lead to serious damage in existing structural elements such as stone, brick or even the existing mortar. In addition, thermal expansion of cement-based mortar is significantly higher; it can even be two times higher than that of lime mortar, which can accelerate deterioration of lime mortar. This can lead to serious problems due to recrystallization of soluble salts [16]. It is known that cement-based mortars are less permeable than lime-based mortars; the presence of small pores that retain moisture prevents evaporation of masonry. In this case, evaporation is ensured through the existing porous material. This causes crystallization of soluble salts in initial construction materials, leading to serious deterioration problems $[16,17]$. On the other hand, the lack of alkali and sulphate in lime prevents damage by salt, due to formation of harmful carbonates and sulphates $\mathrm{Na} / \mathrm{Ca}$ or $\mathrm{Mg}$, as can be seen in case of application of Portland cement [18, 19] (Figure 12). Crystallization of these salts causes significant damage in both new and old structures. On the other hand, due to chemical purity of lime mortar, the possibility of efflorescence is quite low [20].

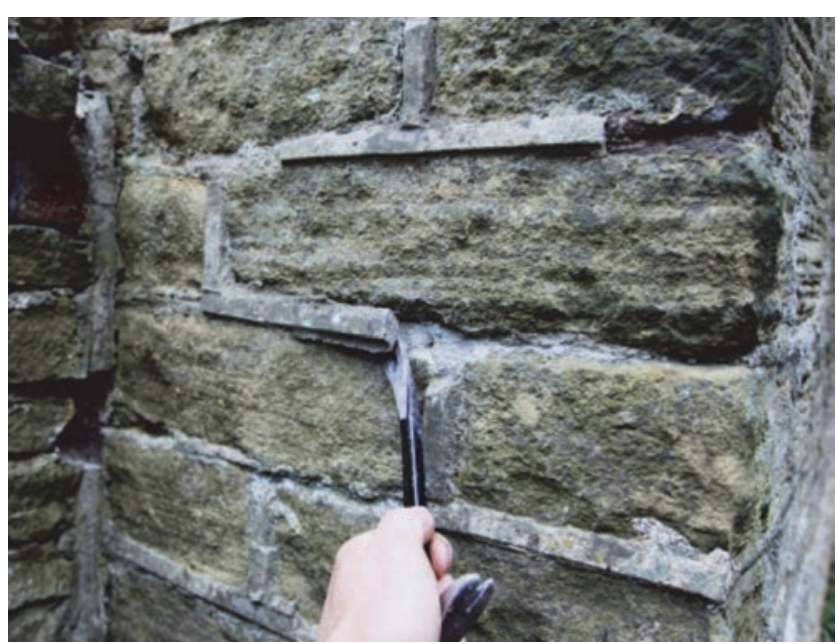

Figure 12. Destruction of cement mortar joint in an old building [21]

One of the most important issues in the restoration and rehabilitation of cultural heritage buildings is undoubtedly the choice of an optimum type and composition of mortar. For lime mortar, the procedure is simple: $1 / 4$ lime and $3 / 4$ sand are mixed with water and mortar is ready. Mason takes the trowel, grabs the mass, and sticks it onto the vertical wall. The mass connects to the wall, binds and cures completely. Such mortar can last hundreds of years. Ingredients are simple, procedures quite common, and yet transformation of simple raw materials into a solid and durable building material is really astonishing. However, previous application of lime mortars showed lack of resistance to atmospheric conditions. Therefore, over a long history of its use, the hydraulics of lime mortar has gradually improved. Current knowledge gained through research is abundant and experts agree that an increase in mortar strength after 28 days, and especially after 6 months, should be as small as possible. In this way, a criterion for proper selection of acceptable mortar composition was formed. However, the question arises with regard to the sampling of mortars from structures erected in, for example, 18th century: is it an original mortar, or a mortar applied during a subsequent restoration work?

The question of sampling original mortar to determine original type of mortar used in historic structures is still an open question, as not all restoration works on structures are recorded. Even if there are records of renewal projects, it is very likely that reliable data on the origin and composition of mortar are missing. At best, it can be assumed that mortar components come from local sources.

Very extensive studies conducted to date have confirmed that it is possible to approximate mortar composition for some construction periods. Thus, in the $15^{\text {th }}$ and $16^{\text {th }}$ centuries lime mortar for such structures was improved by adding crushed and baked brick fragments and brick flour into lime mortar in order to improve hydraulic properties, i.e. to achieve better physicomechanical properties and greater weather resistance. These additives were added in very small quantities and the homogeneity of mortar mixture was not achieved during the construction process.

The choice of aggregate is also very important as it greatly influences mortar structure and its physicomechanical properties, compressive strength in particular.

\subsection{Lime mortar}

The term lime implies both calcium oxide $(\mathrm{CaO})$ or slag lime, calcium carbonate product $\left(\mathrm{CaCO}_{3}\right)$ and a compound obtained after hydration of oxide, for example calcium hydroxide $\left(\mathrm{Ca}(\mathrm{OH})_{2}\right)$, portlandite minerals, known as slaked lime or hydrated lime [22]. An optimum ratio of binder and sand components in the old lime mortars, such as Vitruvius (30 BC) and Alberti (1452), was 1:3. However, many researchers claim that Roman and Greek lime mortar had the ratio of 1:2 [23, 24]. In fact, according to numerous published studies, there is currently no consensus regarding the relationship between binders and aggregates. It can reasonably be concluded that this relationship depends on the type of lime, as well as on the final purpose of mortar (mortar for joints, mortar for grouting and plastering). Additives 
were used in old mortars; in this case, natural additives of organic origin were used in order to improve mortar properties in both fresh and hardened state. Characteristic examples of these additives were whiteness, bull's blood, juices of various fruits, figs for instance, vegetable oil, animal fat, etc. [25]. As far as aggregate is concerned, it is primarily intended to reduce the appearance of cracks during drying, and to provide adequate consistency in the fresh state, and appropriate strength and permeability (porosity) [24].

\subsubsection{Testing of mortars for restauration of bridges}

During the design of mortar composition, it is necessary to take into account specific parameters of durability in the area in which the bridge structure is located, i.e. long-term humidity data, higher number of cyclical changes on sunny sides, significant concentration of exhaust gases from roadway in the immediate vicinity of the structure, and other parameters that could have an unusually disruptive effect on materials that are built into the bridge structure.

The usual practice is to test mortar depending on its use. Usually it is a mortar designed to fill joints, mortar intended for levelling the substrate of bridge pavement with a demand in form of water absorption, mortar for construction, multiple-use mortar, and mortar for injection. According to current experience, mortars that will be exposed to aggressive weather influence should be composed of hydrated lime powder or slaked lime, crushed tufa, fine sand, and a suitable hydraulic additive. Hydrated lime powder, an industrial product of the 20th century, is a slaked limestone in which the quenching occurs with a smaller quantity of (stoichiometric) water. Powdered hydrate is created because large amounts of heat dissipate during the quenching process, which overheats the mass that is being quenched, and the amount of water that is added is not capable of lowering the temperature of the mass that is hydrating, or the excessive temperature of water. The sudden evaporation of this free, chemically unbound water, which leaves the hydrated lime mass, leads to mechanical destruction of its structure, i.e. the lime hydrate is converted into the powder form.

Hydrated lime (slaked limestone in pasty state) is obtained when the quenching is carried out with a much larger amount of water, as has been done for ages.

Presently available hydraulic additives and/or pozzolans can be used in the process of production of mortars for preservation and restoration processes, since it is currently impossible to determine all mortar components that could be used instead of brick (mostly used to improve mortar from Roman period) and ensure adequate hydraulic properties of mortar, i.e. since it would be almost impossible to find out which additive of the alumino-silicate composition was actually the component of the analysed mortar. There is a possibility of using burned bricks with pozzolanic properties, as artificial pozzolan. However, the problem lies in finding a sufficient amount of brick from that time for crushing and grinding. Modern brick is burned at very high temperatures, and in most cases does not exhibit pozzolanic properties. A large quantity of brick would give a reddish colour to the mortar, which would reduce visual compatibility with existing mortars. Other available artificial pozzolans are slag, ash, dust, zeolite tufa, metakaolin, etc. However, the success of their use in the preparation of lime mortar has not been sufficiently investigated. In fact, these mortars have not been tested in Bosnia and Herzegovina due to extensive use of the cement-free hydraulic additive (Albaria struttura) over the last decade on significant cultural and historical structures.

\subsubsection{Mortar with hydrated powder lime in powder}

The experimental testing of mortars, involving the change of certain constituents and different types of hydraulic additives, has been carried out due to the increasingly widespread use of different types of hydraulic additives that do not contain cement in mortar. Mortar used as an etalon had the binder to sand ratio of 1:2 and was made without any additives, as lime mortar. In the second mortar, $10 \%$ of small aggregate grains (mortar 2) was added, in addition to hydraulic additives (Albaria struttura). In the third case, lime was completely eliminated and a hydraulic supplement (Albaria struttura) was used as binder, while the quantity of sand remained unchanged. Test results are shown in Figure 13.

Figure 13 shows that the mortar with no additives has a significantly lower compressive strength and flexural strength under concentrated load compared to the mortar with the addition of Albaria struttura. As generally known, hydraulic mortars with a small amount of binder exhibit a very intense decrease in strength (flexural strength under concentrated load and compressive strength) with the decrease in size of aggregate grains. In mortar 2 (Figure 13), which consists of a large quantity of binder and fine aggregate grains, an
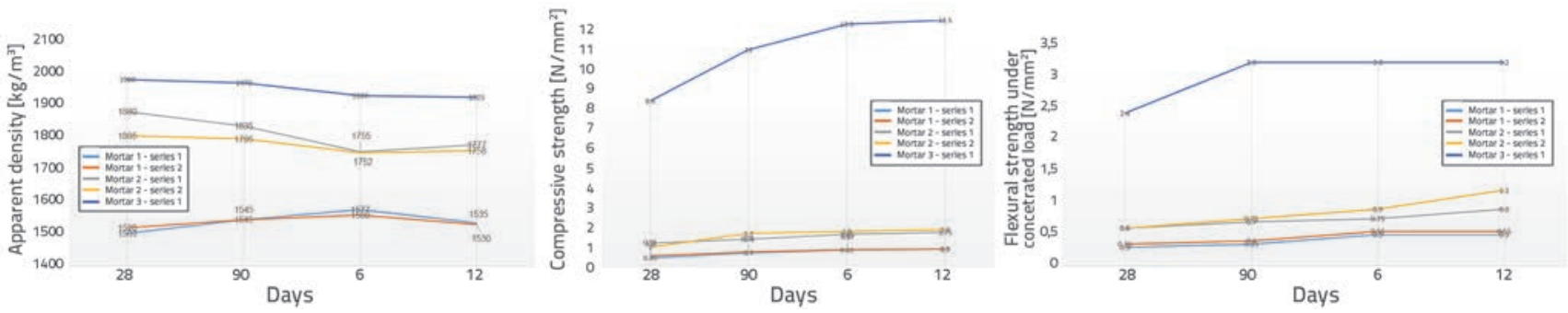

Figure 13. Mortar with hydrated lime 

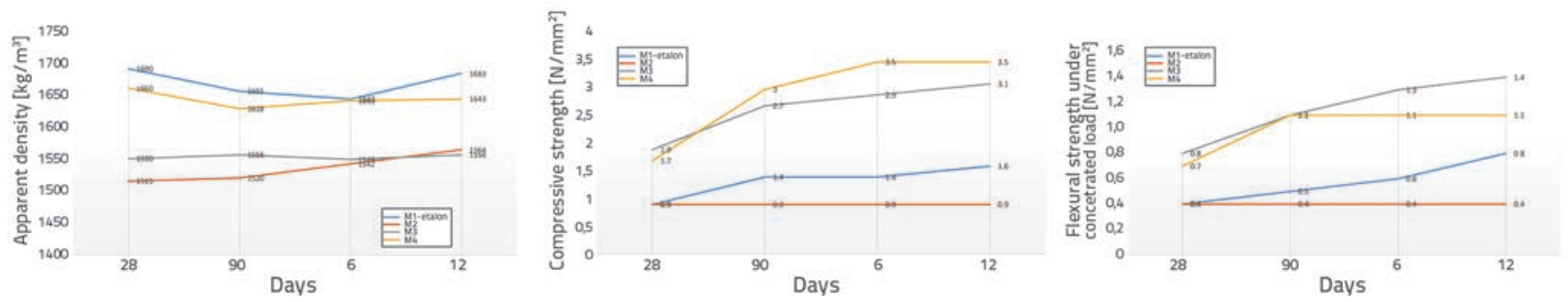

Figure 14. Mortar with slaked lime

increase in strength was observed, which is in accordance with experimental tests performed by many researchers. A $100 \%$ increase in compressive strength was observed with the addition of a hydraulic additive. The application of Albaria struttura has already shown that it provides a significantly high compressive strength, which is not acceptable for restoration of old buildings [26-28]. In mortar 3, this is more than evident, as the 12-fold increase in strength is achieved, which points to the need to adequately determine percentage of participation of hydraulic additives, i.e. of the carrier of strength and stability with regard to atmospheric influences. In the technology of materials, it is assumed that higher-strength materials will have better resistance to atmospheric actions, but it is necessary to bear in mind the fact that an excessive increase in one characteristic might sometimes adversely affect other properties. In other words, in the restoration and reconstruction of cultural and historical monuments, it is necessary to find an adequate measure when proportioning hydraulic additives.

\subsubsection{Mortar with slaked lime}

The mortar with slaked lime is an old recipe that has been used since the Romans and the Greeks, and its use also continued during the era of the Ottomans. In an effort to determine the effect of the hydraulic additive on the mortar made with slaked lime, a certain amount of slaked lime was replaced with a hydraulic additive (Master Emaco S 285 TIX - factory product). In mortar M1 - used as an etalon - a $5 \%$ additive was added. Mortar M2 has $10 \%$ of the same additive, and mortar M3 has $20 \%$ of the same additive. In mortar M4, lime is completely replaced by hydraulic additives (Master Emaco S 285 TIX and Masterlnject 222).

According to Figure 14, the apparent density is almost uniform and the observed differences are attributed to the deviations in mortar treatment (consistency measurement). In case of mortar $\mathrm{M} 2$, where the proportion of hydraulic additive increased from $5 \%$ to $10 \%$, and the quantity of slaked lime was reduced by the same amount, the obtained low values of compressive strength without their increase over time were rather unexpected. The most likely cause - which should additionally be examined could lie in the conditions of nourishment because, although in a small amount, a hydraulic additive of this type certainly required a higher amount of moisture compared to the amount provided under the prescribed conditions of nourishment for lime mortars with smaller amount of hydraulic additive. As expected, an increase in the percentage of hydraulic additive results in significant increase in compressive strength, and also in significant increase in flexural strength under concentrated load.

In order to obtain data, i.e. to confirm the well-known postulate that the porous material of higher strength should have better resistance, primarily to frost action, mortars labelled M3 and M4 were exposed to laboratory test for frost action, consisting of 25 alternating freeze and thaw cycles. The obtained results were unexpected because the mortar with better mechanical properties showed significantly poorer behaviour with regard to frost and total destruction.

According to most recent findings of the authors, mortars that are made with air binders (lime and gypsum), which have extremely low strength (up to $1 \mathrm{MPa}$ ), the ratio of flexural strength under concentrated load to compressive strength is high and reaches up to 1.0. In addition, it has been established that, with the increase in hydraulic characteristics, i.e. by increasing mortar strength, the stated strength ratio reduces conclusively with the cement mortar where this ratio ranges from 5 to $10 \%$.

\section{Conclusion}

Stone bridges remain as a permanent seal of the Ottoman Empire rule in Bosnia and Herzegovina. In order to obtain stone and mortar data for use in reconstruction of bridges from the Ottoman period, characteristic petrographic types of stone and lime mortars were tested using cement-free hydraulic additives. As to mortar containing a cement-free hydraulic additive (Albaria struttura), it was confirmed that this mortar exhibits high compressive strengths that are not acceptable for the restoration of old buildings. This has to be taken into account in determining appropriate proportion of this hydraulic additive. Adding hydraulic additives to slaked lime resulted in higher mortar strength but, unexpectedly, mortars with better mechanical properties (without lime), exhibited poorer resistance to frost, and total destruction was observed. Further research in this field is planned but with natural hydraulic additives. 


\section{REFERENCES}

[1] Gojković, M.: Stari kameni mostovi- anatomija, patologija, zaštita, sanacija, konzervacija, Naučna knjiga, Beograd, 1989.

[2] Maksimović, M.: Eksploatacija, ispitivanje, primjena arhitektonskog kamena, Beograd, 2006.

[3] Tehnička enciklopedija br. 6, Jugoslovenski leksikografski zavod Zagreb

[4] Hansen, E.F., Balen, K.V., Elert, K., Rodriquez-Navarro, C., Simon, S.: Preservation of lime mortars and plasters. The $\mathrm{GCl}$ Project Bibliographies Series, 2003.

[5] Böke, H., Çizer, Ö., İpekoğlu, B., Uğurlu, E., Serifaki, K., Toprak, G.: Characteristics of lime produced from limestone containing diatoms, Construction and Building Materials, 22 (2008), pp. 866-874

[6] Papeš, J.: Tektonska građa teritorije SR BiH, Sarajevo: Geoinstitut llidža, 1988.

[7] http://www.fzzg.gov.ba/geoloske-karte, Federalni zavod za geologiju Bosne i Hercegovine

[8] Barić, Lj., Trubelja, F.: Minerali Bosne i Hercegovine-Nesilikati, Svjetlost, 1984.

[9] Bilbija, N., Matović, V.: Primijenjena petrografija - svojstva i primjene kamena, GK Beograd 2009

[10] Galić, A., Prskalo, M.: Sedra - kamen koji teče, Prvi simpozij Hercegovina - zemlja kamena, Zbornik radova, pp. 131-143

[11] Kurtović, A.: Kamen u graditeljstvu, Građevinski fakultet, Sarajevo, 2014.

[12] Kurtanović, R.: Ležišta nemetalnih mineralnih sirovina, Univerzitet u Sarajevu, Fakultet za metalorgiju i materijale Zenica, 2000

[13] Maurenbrecher, A.H.P.: Mortars for repair of traditional masonry Practice Periodical Struct, Design Construct, 9 (2004), pp. 62-65.

[14] Collepardi, M.: Degradation and restoration of masonry walls of historic buildings, Mater. Struct., 23 (1990), pp. 81-102.

[15] Van Hees, R.: Damage diagnosis and compatible repair mortars, RILEM, International Workshop on Historic Mortars: Characteristics and Tests, RILEM TC-167 COM, Paisley, (1999), pp. 27-35.

[16] Shafer, J.: The weathering of natural building stones, Department of Scientific and Industrial Research, Special Report 18, London 1972 , p. 149
[17] Ken, R.: Role of lime cycles in historic buildings, Building Engineer, 70 (1995), pp. 1-2

[18] Maravelaki-Kalaitzakia, P., Bakolasb, A., Moropouloub, A.: Physico-chemical study of Cretan ancient mortars, Cement and Concrete Research, 33 (2003), pp. 651-661

[19] Hansen, E.F., Rodríguez-Navarro, C., Van Balen, K.: Lime putties and mortars: Insights into fundamental properties. Studies Conservation, 53 (2008), pp. 9-23.

[20] Elert, K., Rodriguez-Navarro, C., Pardo, E.S., Hansen, E., Cazalla, O.: Lime mortars for the conservation of Historic Buildings, Studies in Conservation, 47 (2002), pp. 62-75

[21] http://www.heritage-house.org/what-is-pointing-and-whatdoes-it-do.html

[22] Boynton, S.R.: Chemistry and Technology of Lime and Limestone, $2^{\text {nd }}$ Edition, 1980

[23] Oates, J.A.H.: Lime and Limestone Chemistry and Technology, Production and Use, Wiley-VCH, 1998

[24] Elsen, J.: Microscopy of historic mortars - a review, Cement Concrete Res., 36 (2006), pp. 1416-1424.

[25] Moropoulou, A. Bakolas, A., Anagnostopoulou, S.: Composite materials in ancient structures, Cement Concrete Compos., 27 (2005), pp. 295-300.

[26] Demir, C., Dogu, E., Ispir, M., Ilki, A.: Seismic Behavior of Ottoman Empire Classical Period Stone Masonry Walls, 10CUEE Conference Proceedings, $10^{\text {th }}$ International Conference on Urban Earthquake Engineering, Tokyo Institute of Technology, 1-2 March 2013, Tokyo, Japan

[27] Ghiassi, B., Oliveira, V.D., Marques, V., Soares, E., Maljaee, H.: Multi-level characterization of steel reinforced mortars for strengthening of masonry structures, Materials \& Design, 2016, Elsevier

[28] Bosch Roig, L., Navarro Bosch, A., Martínez Boquera, A., Alonso Durá, A., Bosch Reig, l.: Consolidación Estructural De Los Puentes De Serranos Y De La Trinidad De Valencia, Proceso Y Ensayos De Puesta En Obra, Arché. Publicación Del Instituto Universitario De Restauración Del Patrimonio De La Upv - Núm. 3 (2008), pp. 221232. 